\title{
Phonology and Morphology Interferences
}

\section{In Bukalapak Advertisement Januari-July 2017 Edition}

Ratnawati

Fakultas sastra, Universitas Pamulang, Indonesia

\section{Tri Pujiati}

dosen00356@unpam.ac.id

Fakultas sastra, Universitas Pamulang, Indonesia

Received : 24 April 2018; Accepted : 30 May 2019

URL : http://ejournal.iainpalopo.ac.id/index.php/ideas

\begin{abstract}
This research is aimed at explaining the form of language interferences in bukalapak advertisement edisi during January - July 2017. This research used descriptive qualitative method through sociolinguistics approach. The object of the research were the utterances in the Bukalapak advertisement which display by official youtube during Januari up to July 2017. The total number of data used was 131 data. Those data were collected through recording and notetaking. Based on the data analysis, it is found that there is interferences in the Bukalapak advertisement which display by official youtube during Januari up to July 2017. The phonology interferences is divided into two types namely deletion of the sound and addition of the sound. While the morphology interference is the errors in affixation on some Indonesian words.
\end{abstract}

Keywords: phonology interferences, morphology interference, Sosiolinguistic

\section{Introduction}

In the trade world, communication hold a main role which cannot be ignored. Communication use mass media which usually use to deliver information or advertisement. One of the advertisement in Indonesia is the Bukalapak advertisement. Offering product and services advertisement by Bukalapak and display on Januari up to July 2017 contain with the relation between language and society in advertising form. In those advertisements, there are some foreign language variation including English which is used together with Indonesian. The aim of the advertisement offering is to 


\section{Ratnawati \\ Tri Pujiati : \\ Phonology And Morphology Interferences \\ In Bukalapak Advertisement Januari-July 2017 Edition}

invite and to elicit the buyers to do transaction through online by using application of Bukalapak. Sometimes an advertising is made to commercialize some language expression which is not commonly use by the society. Therefore, it is appeared some ungrammatical based on the rules of Indonesian pattern. It is always performance by language society. They always claim that those expression were created by theirselves, therefore, those are just understood by specific community.

According to Nababan (1984), interference is an error which is caused by the habit of uttering an utterance of one language towards other language included the pronunciation, phonology, grammatical and vocabulary. Interference is a deviation of language norms in using a language as a result of knowing other language. Transfer in language contact can be happened in all aspects of linguistics such as phonology, morphology, syntax, semantic, also lexicon.

The previous research on language interferences have been conducted by some former researchers, such as Haryanto (2005) entitled "Interferensi Bahasa Inggris, Bahasa Arab, dan Bahasa Jawa ke dalam Bahasa Indonesia pada Wacana Resensi di Surat Kabar Suara Merdeka Bulan Juni dan Oktober 2004", Suryanto (2005) entitled "Interferensi Bahasa Inggris ke dalam Bahasa Indonesia pada Novel "Odah" Karya Muhammad Diponegoro", Meinawati (2008) "Interferensi Dalam Bahasa Indonesia Pada Iklan Televisi”, Listyoningsih (2008) "Interferensi Dan Integrasi Dalam KolomKolom Edan Prie G.S “, Sukoyo (2011) "Interferensi Bahasa Indonesia dalam Acara Berita Berbahasa Jawa "Khutane Dhewe" di TV Borobudur Semarang Darini (2013) entitled "Interferenssearci Fonologi, Morfologi, dan Leksikal Dalam Komunikasi Formal Mahasiswa Sastra Indonesia Fakultas Ilmu Budaya Universitas Airlangga" Suindratini et al (2013) "Interferensi Bahasa Bali Dan Bahasa Asing dalam Cerita Lisan Bahasa Indonesia Kelas VII Siswa SMP Negeri 10 Denpasar”, Kihi-kihi (2015) "Interferensi Fonologi Bahasa Galela Ke Dalam Bahasa Tobelo", Prihandoko (2015) study about interference and integration Betawi language towards Betawi kota language by using sosiolinguistic approach. This research tries to complete the previous research related to interference of language in advertising which is displayed in official Youtube channel of Bukalapak.

\section{Method}

The method used of this research was descriptive research by using sociolinguistic approach.. The data source were advertisement of trade online of Bukalapak.com Januari up to July 2017 which is displayed in official Youtube channel of Bukalapak.

\section{Results}

The following is the findings of this research: 
Tabel 1

The findings on Interference pada Iklan Bukalapak pada Edisi Januari sampai Juli 2017

\begin{tabular}{|c|c|c|c|}
\hline No. & $\begin{array}{c}\text { Types of } \\
\text { Interference }\end{array}$ & Utterances & Code \\
\hline 1. & Fonologis & $\begin{array}{l}\text { Nego lagi nego lagi } \\
\text { Perbedaan bukan untuk unpren-mengunpren } \\
\text { Bukan pula untuk bersetru } \\
\text { Makhin beragam makhin lengkap } \\
\text { Bukalapak emang cingcai } \\
\text { Harga santai, kagak lebay } \\
\text { Dinego aje say, pasti bisa say } \\
\text { Pesen tivi flat sekrin bisa } \\
\text { Makin banyak kamu belanja makin banyak amplop } \\
\text { yang kamu dapet buat belanja selanjutnya } \\
\text { Buka aja Bukalapak }\end{array}$ & $\begin{array}{l}\text { D } 9 \\
\text { D } 23 \\
\text { D } 27 \\
\text { D } 31 \\
\text { D } 33 \\
\text { D } 34 \\
\text { D } 35 \\
\text { D } 53 \\
\text { D } 73\end{array}$ \\
\hline 2. & Morphology & $\begin{array}{l}\text { Ambil HP say, tinggal nego sampai cingcay } \\
\text { Jangan lupa masukkin angka nego say } \\
\text { Setuju harga penawaran atau nego lagi say } \\
\text { Mau jadi sambilan atau kerja tetap, semua bisa jadi } \\
\text { agen Bukalapak } \\
\text { Dapatkan tiga juta rupiah setiap minggunya } \\
\text { Belanja sekarang dan dapetin amplopnya } \\
\text { Caranya pilih barang lalu lakukan transaksi } \\
\text { Mau berbuka sambil dapat amplop? } \\
\text { Beli apa aja, say } \\
\text { Bayar apa aja, say }\end{array}$ & $\begin{array}{l}\text { D } 39 \\
\text { D } 41 \\
\text { D } 42 \\
\text { D } 55 \\
\text { D } 56 \\
\text { D } 70 \\
\text { D } 71 \\
\text { D } 77 \\
\text { D } 113 \\
\text { D } 114\end{array}$ \\
\hline
\end{tabular}

\section{DISCUSSION}

\section{Analysis Interference Phonologis}

Phonological Interference happened when a speaker expresses words from one language by putting some sounds from other language. Phonology Interference is differentiated into two types namely : deletion of the sound and addition of the sound.

\section{a. Interference phonology through deleting sound}

Data D 9 shows phonological interference which is noticed by the word nego which is in the basic form "negosiasi" and formed from 9 phonemes [negosiasi]. However, the speaker only utter "Negosiasi" by deleting phonemes /s/, /i/, /a/, /s/, and /i/ 


\section{Ratnawati \\ Tri Pujiati : \\ Phonology And Morphology Interferences \\ In Bukalapak Advertisement Januari-July 2017 Edition}

in the fifth position until the end of the word. The phenomenon of the phoneme deletion can be categorized as "contraction" form. Sometimes the speaker utter the word negosiasi becomes jadi nego. The speaker speak too fast, then they do not pay attention to the correct sound of words. It is also happened in the advertisement which in the fast conversation or in the informal situation. The makers of adverstisements always shorten the utterances.

In the data D 27, there is a phonology interference, namely in the word "bersetru". It has nine original sounds. It consists of $/ \mathrm{b} / / \mathrm{e} / / \mathrm{r} / / \mathrm{s} / / \mathrm{e} / / \mathrm{t} / / \mathrm{e} / / \mathrm{r} / / \mathrm{u} /$. However, it the real utterance, it is found that the speaker utters the word berseteru by deleting the phoneme /e/ at the seventh order in the middle of the word. The phenomenon of the phoneme deletion sometimes happened because the speaker ignores the sound. Therefore, the speaker utter "berseteru" becomes "bersetru". The original form of bersetru has phoneme /e/ which is in middle of two consonants. It should be pronounced clearly becomes berseteru [bərsətəru].

In the data D 33, there is a phonological interference. The data of phonological interference is emang. The phoneme emang is in the inappropriate form. It is because the phoneme phoneme $/ \mathrm{m} /$ is deleting in the front position. The correct form of emang is memang. The form has consonant $/ \mathrm{m} /$ which is followed by vocal sound, then it is articulated nasally namely memang [mEmay]. The deletion of vocal or consonant sound always happen in the utterances process in an advertisement since it is needed to be in a short duration. It is also expereineced by the maker of Bukalapak advertisementi Januari 2017 edition. The reduction of phonology is conducted to solve the problem about the limited duration of the advertisement. Unfortunately, this gives effect on the phonological aspect of one language.

In the data D 35 and D 78, there are also phonological interferences. The form of phonological interference is deleting and exchanging the phoneme. It can be seen in the word aje and aja. A couple of the word has the same basic form, namely saja. Saja has four phonemes which consists of $/ \mathrm{s} / / \mathrm{a} / / \mathrm{j} / / \mathrm{a} /$. In the word aje, the phoneme $/ \mathrm{s} /$ which is in the first position of the word is deleting. It is followed by phoneme /a/ which is in the end position also changing into phoneme /ə/. While in the word aja is in the incorrect form since the phoneme /s/ which is in the first position is deleting. The data is experiencing the deleting phonological interference is influenced by Jakarta dialect [aja] and Betawi [ajə]. Both of the forms has the similar form and has phoneme $/ \mathrm{s} /$ in the initial position and /a/ in the end position. Each of phoneme is separated by vocal and consonant sound sequently. Those can be uttered fricatively namely saja [saja]. In the Bukalapak advertisement Januari 2017 edition. The maker probably thinks that the use of aja dan aje are not different from the original form namely saja, Most of the advertisement makers consider that the phenomenon of language interference is not a big problem. The advertisement makers realize about the phenomenon. In fact, the language interference can omit the originality of the language. However, the phenomenon does not have special attention from the advertisement makers who have 
clearly only commercial motivation.

In the data D 35, there is a phonological interference. In the interference, there is a deletion of phoneme process. It is signed by the word say by the speaker. The basic form of word say is sayang. Therefore, the appropriate form of word say is sayang by not deleting some phonemes namely /a/, /y/, /a/, / $/$. The reason for this phenomemon is to shorten the advertisement. The main reason for doing the use of slang language is to get the society attention which is easier to be accepted by them. However, it can contribute to the break of the language rules.

\section{b. The Analysis of phonological interference through the changing of phonemes}

In data D 23, there is a phonological interference towards English words.. Phonological interference happened in the word anpren. There is a changing. In the English word unfriend. The phonological interference of bahasa Indonesia towards foreign language is usually happened to have a suitable tongue movement in Indonesian. However, in the context of Bukalapak advertisement Januari 2017 edition, the other reason is to create a humorous sense to get the society attention on the advertisement.

In the data D 31, there is a Javanese phonological interference towards Indonesian, namely in the phoneme makhin. The form of the phonological interference is the interference of Javanese sound to Indonesian. In java language, there is a different between the phonemes $/ \mathrm{k} /$ and $/ \mathrm{kh} /$. Indonesia only has phoneme $/ \mathrm{k} /$. The form makhin is an inappropriate of makin. Makhin is the form which has experienced through the addition of phoneme $/ \mathrm{h} /$ in the fourth position in the basic word makin. The result is that there is a double consonant which is called as cluster, namely $/ \mathrm{kh} /$. The cause of the cluster appearance is that the background of the speaker as Javanese. Therefore, it is appeared the double consonant in the word makin.

In data $\mathrm{D} 53$, there is an exchanging phonemes as phonological intereference, namely in the word pesen. The speaker pronounce phoneme [a] as [ə]. The correct form is pesan. It is not suitable if pesen is used in the formal communication. However, in the context of an advertisement, the informal language is always used. The word pesen is more frequently used than pesan as in data D 35 dan D 78. The deletion and the changing is influenced by betawi dialect which always changing the vocal [a] becomes vocal [ə].

In the data D 73, there is a phonological interference namely the changing of phoneme in the word dapet. The formal form of the word is dapat. However, in Bukalapak advertisement, the word is pronounced as [dapət]. The vocal [a] which is in middle of two consonants in the word has been experiencing a changing into [ə].

\section{The Analysis of Morphological Interference}

Morphological Interference is happened if in the forming of a word absorbs the affixes from other languages. The structure deviation happened in language contact among the language they use and other languages that has been mastered. The 


\section{Ratnawati \\ Tri Pujiati : \\ Phonology And Morphology Interferences \\ In Bukalapak Advertisement Januari-July 2017 Edition}

morphological interference included the errors in putting ending and prefixing. Based on the collected data,it is found that the morphological interference in the Bukalapak Januari up to July 2017 is the interference in affixation deviation in words of Indonesian.

In the data D 39, there is a morphological interference, namely in the word nego. The word in data D 39 has undertaken a morphological interference in the form of prefix and suffix deletion of the word nego. In addition, nego is basically come from the word negosiasi. It seems that the maker of Bukalapak advertisement Januari 2017 edition is interested to shorten the word. In the correct form, the word nego should have prefix and suffix. The complete word should be dinegosiasikan.

In the data D 41, there is a morphological interference, namely in the word masukkin. The form of the interference is the error in the use of prefix -mem and the deviation of the use suffix -kan in the word masukkin. The advertising maker ommit the prefix and it remain only the suffix. The suffix is also misinterpretation. Therefore, the correct form of the word is memasukkan.

In the data D 42, there are two words experiencing the morphological interferences. The interference are the deviation of prefix and suffix deletion. First, in the word setuju, the less addition of prefix -mem and sufix $-\mathrm{i}$. and prefix -di also sufix -kan in the morpheme nego which also experience interference previously. In the advertisement context, the maker of the advertisement does not care on language aspect. Therefore, the forms of morphological interference in the affixation are always found. Examples of the affixation intereferences such as in the words setuju dan nego. Those should be menyetujui and dinegosiasikan.

In the data D 55, there is an interference in the affixation matter, namely in the morpheme jadi. There should be prefix -men in the word jadi. the word jadi should be in form jadi $=$ menjadi.

In the data D 56, there is an interference at morphological level, namely at word minggunya. The word that has been experiencing on morphological interference is using particle -nya. Particle -nya is usually used to sign an own. However, the particle -nya must be used appropriately to make an effective use of a language. Therefore, the use of word minggunya, is better used without particlel -nya, then in order to make it more effective and also it is not confusing.. The context of own in minggunya is not clear. The ambiguity of context can be seen as ineffective expression. Therefore, the advertisement maker should realize the ineffective of language use.

In data D 70, there is morphological interference, namely in the words belanja dan dapetin. The form of the morphological interference in the both of the words is the errors in affixation. There should be prefix -ber and sufix -kan sequently in the words belanja and dapetin. The morphological interference from affixation always happened in the Indonesian. The form of the interference consists of verb + sufix - in. No matter what the last sound of the words, whether it is vocal or consonant. It is always added with the suffix -in. However, the rule does not exist in affix of Indonesian formally. The 
word dapetin has basic form dapat. It is ended with wiyandana (consonant) $-\mathrm{t}$. The form dapetin is changing in active verb in Indonesian. The word dapetin lis more appropriate if it is added with sufix -kan becomes dapatkan. Then, based on the rules of the Indonesian, the word belanja dishould be added with the prefiks -ber which is the most productive prefix in Indonesia. Therefore, it should become berbelanja. In Bukalapak advertisement, unfortunately the affixation has not been paid attention. The maker of the advertisement is only focused on the safe and aesthetic of language as etalase in advertising without the formality of the language.

In the data D 71, there is a morphological interference in the words pilih and lakukan. Both of the words experience the morphological interference and and the particle. Both of the words should be ended with particle -lah. Because the addition of particle -lah will show the real action meaning of both words. Pilih becomes pilihlah, lakukan becomes lakukanlah. The addition of particle -lah is appropriate. It is because the meaning context of the advertisement is asking the watchers to buy by using online application Bukalapak. Words pilihlah and lakukanlah have enforcement to society who are watching Bukalapak advertisement to shop and choose the thing that have been published online in the Bukalapak website easily.

In the data D 77, there is a morphological interference. It is signed in the word dapet. The form of morphological interference in the data D 77 is an error in affixation, namely the deleting the prefix - men and sufix -kan in the word dapet. The affix in the initial and in the end should be a confix in the form of verb. The word dapet, should be given an affixation process to be in the perfect form namely mendapatkan. However, in the context of Bukalapak,advertisement, the concept verb meaning in a word has been ignored. The maker of advertisement is just thinking about the "understandable". As long as it is accepted by the society easily. Therefore, it is suggested to the advertisement maker to keep using the correct vocabulary and should be supported not only rational aspect but also language formality touch.

In the data D 113 happened a morphological interference, namely in the word beli. The form of the morphological nterference is the error by deleting the confix pean. The appropriate form of morpheme beli safter experiencing the morphological process namely affixation is pembelian. The confix pe-an is the prefix forming the noun. It is necessary for data D 113 to have morphological process in the form of pe-an affixation because of the relation of the meaning context. The complete form of the data D 113 is beli apa aja, say, kthe word beli is not functioned as verb but a noun. Therefore, the morpheme beli gets a force meaning from the confix pe-an which refers to the action. However, the advertisement maker make unclear limit between the verb and the noun by not using the affixation. The result of the unclearliness is the ambiguity of the word influence the concept of the meaning. Unfortunately, ironically, the advertisement maker ignore the ambiguity in Bukalapak advertisement July 2017 edition.

In the data D 114 exists a morphological intereference. It is in the word bayar. The form of morphological interference in the data D 114 is an error by deleting the confix pe-an which refers to action in the word bayar. The phenomenon in the data is 
Ratnawati

Tri Pujiati :

Phonology And Morphology Interferences

In Bukalapak Advertisement Januari-July 2017 Edition

similar to the data D 114. Therefore, the appropriate form of bayar after the morphology process is pembelian.

The correct form of the morphological interference as follows:

a) Ambil HP say, tinggal dinegosiasikan sampai cingcay (D 39)

b) Jangan lupa memasukkan angka nego say (D 41)

c) Menyetujui harga penawaran atau dinegosiasikan lagi say (D 42)

d) Mau menjadi sambilan atau kerja tetap, semua bisa menjadi agen Bukalapak (D 55)

e) Dapatkan tiga juta rupiah setiap minggu (D 56)

f) Berbelanja sekarang dan dapatkan amplopnya (D 70)

g) Caranya pilihlah barang dan lakukanlah transaksi (D 71)

h) Mau berbuka sambil mendapatkan amplop? (D 77)

i) Pembelian apa aja, say (D 113)

j) Pembayaran apa aja, say (D 114)

\section{Conclusion}

The utterances at the Bukalapak advertisement Januari up to Juli 2017 edition consist of some language interferences, especially the foreign language, local language and slang language towards Indonesian language. In an advertisement, language becomes a powerful interest to get the society attention. Unfortunately, it is ironic when the language in an advertisement is disturbed by the foreign language and slang language to get the successful and the goal of the advertisement.

\section{References}

Alwasilah, A Chaedar. (1990). Sosiologi Bahasa. Bandung: Penerbit Angkasa.

Arikunto, Suharsimi. (2003). Prosedur Penelitian, Suatu Praktek. Jakarta: Bina Aksara.

Bloomfield, Leonard. (1996). Language. Delhi: Motilal Banarsidass Publishers.

Chaer, Abdul dan Leonie Agustina. (2010). Sosiolinguistik Perkenalan Awal. Jakarta: Rineka Cipta.

Darini, Annura Wulan. (2013). Interferensi Fonologi, Morfologi, dan Leksikal dalam Komunikasi Formal Mahasiswa Sastra Indonesia Fakultas Ilmu Budaya Universitas Airlangga. Surabaya: Universitas Airlangga.

Djajasudarma, Hj. T. Fatimah. (2006). Metode Linguistik: Ancangan Metode Penelitian Dan Kajian. Bandung: PT Refika Aditama.

Hamers, Josiane. F dan Michel H. A. Blanc. (1995). Bilinguality and Bilingualism. Melbourne: University of Cambridge Press.

Harefa, Andrias. (2003). Agar Menulis Mengarang Bisa Gampang. Jakarta: Gramedia Widiasarana Indonesia.

Hoffmann, Charlotte. (2014). An Introduction to Bilingualism. New York: Routledge Publisher.

http://ibrary.usu.ac.id/download/fs/fs-mulyani.pdf-Similar pages The Truth Is Out 
IDEAS, Vol. 7, No. 1, June 2019

ISSN 2338-4778 (Print) ISSN 2548-4192 (Online)

There

diakses

pada

17

November

2017.http://www.komunikasipraktis.com/2014/10/daftar-definisi-komunikasi-

menurut-para-ahli.html diakses pada 17 November 2017.

Huda, Nuril dkk, (1981). Interferensi Bahasa Madura Terhadap Bahasa Indonesia. Jakarta: Buku Kita.

Jendra, I Wayan. (1991). Dasar-dasar Sosiolinguistik. Denpasar: Ikayana.

Keraf, Gorys. (2000). Diksi dan Gaya Bahasa. Jakarta: Gramedia.

Kihi-kihi, Martina. (2015). Interferensi Fonologi Bahasa Galela Ke Dalam Bahasa Tobelo. Manado: Universitas Sam Ratulangi.

Kridalaksana, Harimurti. (2001). Kamus Linguistik. Jakarta: PT. Gramedia.

Listyoningsih, Ari. (2008). Interferensi Dan Integrasi Dalam Kolom-Kolom Edan Prie G.S "Hidup Bukan Hanya Urusan Perut" (Suatu Tinjauan Sosiolinguistik). Surakarta: Universitas Muhammadiyah Surakarta.

Meinawati, Euis. (2010). Interferensi Dalam Bahasa Indonesia Pada Iklan Televisi dalam Jurnal Wanastra Vol.I No.2 September 2010.

Moleong, Lexy. (2003). Metode Penelitian Kualitatif. Bandung: Remaja Rosdakarya.

Nababan, P.W.J. (1984). Sosiolinguistik. Jakarta: Gramedia.

Ohoiwatun, Paul. (2002). Sosiolinguistik. Jakarta: Visipro.

Prihandoko, Bayu. (2015). Integrasi dan Interferensi Bahasa Betawi Ora Terhadap Bahasa Betawi Kota. Pamulang: Universitas Pamulang.

Rhenald, Kasali. (1995). Manajemen Periklanan Konsep dan Aplikasinya di Indonesia (edisi empat). Jakarta: Pustaka Utama Graffiti.

Sudaryanto. (1993). Metode dan Aneka Teknik Analisis Bahasa (Pengantar Penelitian Wahana Kebudayaan secara Linguistik). Yogyakarta: Duta Wacana University Press.

Sukoyo, Joko. (2011). Interferensi Bahasa Indonesia Dalam Acara Berita Berbahasa Jawa "Kuthane Dhewe" di TV Borobudur Semarang. Semarang: Universitas Negeri Semarang.

Supriyadi. (2011). Interferensi Bahasa Asing Pada Iklan Lowongan Pekerjaan Di Surat Kabar Kompas Edisi Bulan Mei 2010. Surakarta: Universitas Muhammadiyah Surakarta.

Suryanto, Gatot. (2005). Interferensi Bahasa Inggris ke dalam Bahasa Indonesia pada Novel "Odah" Karya Muhammad Diponegoro. Surakarta: Universitas Muhammadiyah Surakarta.

Suwito. (1983). Pengantar Awal Sosiolinguistik: Teori dan Problema. Surakarta: Henary Offset.

Suwito. (1985). Sosiolinguistik. Surakarta: Henary Offset.

Wardaugh, Ronald. (1995). An Introduction to Sociolinguistics Third Edition. Britania Raya: Blackwell Publishers.

Winarno, Surakhmad. (2004). Pengantar Penelitian Ilmiah, Dasar, Metode, dan Teknik. Bandung: Tarsito

Yusuf, Suhendra. (1998). Fonetik dan Fonologi. Jakarta: Gramedia. 